\title{
History of disorders of thyroid dysfunction
}

A.M. Ahmed ${ }^{1}$ and N.H. Ahmed ${ }^{2}$

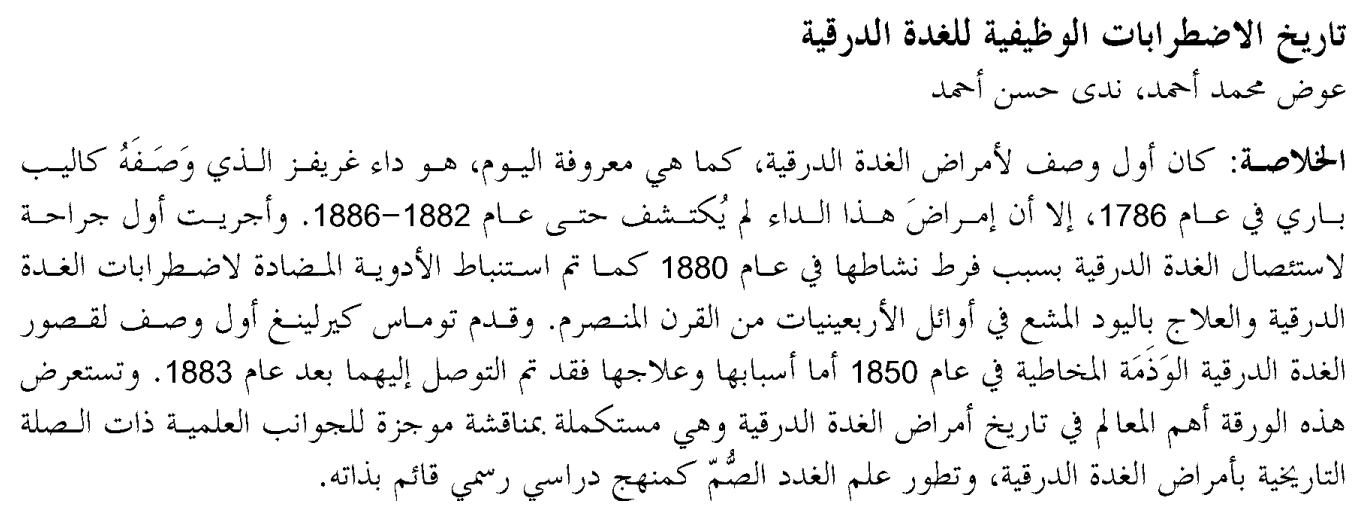

ABSTRACT The first description of thyroid diseases as they are known today was that of Graves disease by Caleb Parry in 1786, but the pathogenesis of thyroid disease was not discovered until 1882-86. Thyroidectomy for hyperthyroidism was first performed in 1880, and antithyroid drugs and radioiodine therapy were developed in the early 1940s. Thomas Curling first described hyopothyroidism (myxoedema) in 1850 and the cause and suitable treatment were established after 1883. This paper reviews the main landmarks in the history of thyroid disease, supplemented by a brief discussion of the historically relevant scientific aspects of the thyroid gland, and the evolution of endocrinology as a formal discipline.

\section{Histoire des troubles dysthyroïdiens}

RÉSUMÉ La première description des pathologies thyroïdiennes, telles qu'on les connaît aujourd'hui, a été celle de la maladie de Graves par Caleb Parry en 1786, mais la pathogenèse de l'affection thyroïdienne n'a pas été découverte avant 1882-1886. Une thyroïdectomie pour hyperthyroïdie a été réalisée pour la première fois en 1880 , et les antithyroïdiens et le traitement par l'iode radioactif ont été mis au point au début des années 1940. Thomas Curling fut le premier à décrire l'hypothyroïdie (myxoedème) ainsi que sa cause en 1850 et un traitement adéquat a été établi après 1883. Cet article procède à un examen des principales étapes dans l'histoire de la pathologie de la thyroïde, avec une brève discussion des aspects scientifiques concernant la glande thyroïde qui ont eu une importance historique, et de l'évolution de l'endocrinologie en tant que discipline à part entière.

${ }^{1}$ Faculty of Medicine, University of Bahr Elghazal, Khartoum, Sudan (Correspondence to A.M. Ahmed: awad_sd@hotmail.com).

${ }^{2}$ Ministry of Health, Khartoum, Sudan.

Received: 17/08/03; accepted: 22/03/04

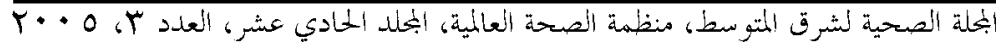




\section{Introduction}

The history of thyroid disease is an example of the close inter-relationship of basic and clinical sciences. Although we can see a slow advancement in knowledge about the clinical features of thyroid disease since the dawn of the 20th century, the methods of investigation and treatment advanced rapidly.

This paper reviews the main landmarks in the history of thyroid disease, starting with a brief outline of the evolution of modern endocrinology. Many endocrine concepts such as feedback mechanisms, replacement therapy and the use of isotopes were first established during studies on the thyroid gland. Although the aim of the paper was to discuss the historical aspects of thyroid disease, we have supplemented the review with a description of the historical developments in our knowledge of anatomy and physiology of the thyroid gland.

\section{Endocrinology: historical landmarks}

Some endocrine facts, such as the sequelae of castration, are deeply rooted in the past. Frederick Ruysch (1638-1731), a Dutch anatomist, was the first to speculate, in 1690, that an organ such as the thyroid pours into the blood substances of physiological importance [1]. The French scientist Theophile de Bordeu (1722-76) had a similar theory [1]. The Ruysch and Bordeu speculations were easily criticized by the lack of any experimental proof. But the real father of endocrinology who set its principles as a formal discipline was French physiologist Claude Bernard (1813-78). In 1855 , Bernard introduced the term "internal secretions" when he was studying the role of the liver in sugar metabolism. He stated that the external secretions form the bile and the internal secretions form the blood sugar [2].

From 1855 to 1902 important research in endocrinology was carried out [3]. Addison wrote an account on the disease of the suprarenal capsule [1]. Brown-Séquard demonstrated that in animals death from adrenalectomy could be delayed by infusion of blood from healthy animals. In 1889 Minkowski and Von Merring performed the experimental production of diabetes [1]. By the end of the 19th century a number of diseases such as Graves disease and acromegaly were described along with their probable relation to a glandular dysfunction [3].

English physiologists William Bayliss (1860-1924) and Ernest Starling (18661927) made important discoveries in 1902 [3]. While they were studying the effects of "pancreatic juices" on the duodenal mucosa, they isolated a substance, giving it the name "secretin". When secretin was injected into the bloodstream of an experimental animal, it resulted in marked increased secretion from the pancreas. This result reinforced Bernard's concept of internal secretion [3]. In 1905 Starling coined the term "hormone" for this internal secretion (including his secretin). The word hormone was derived from a Greek phrase meaning "to set in motion". Thus, secretin was the first hormone to be isolated. The term "endocrine" can be traced to Starling who differentiated between endocrine and exocrine secretions [1].

The history of endocrinology is not complete without a mention of the master of the endocrine glands, the pituitary. The pituitary gland was named by the Belgian anatomist Andreas Vesalius (1514-64) who believed that it secreted mucus through the nose (derived from the Latin word pituita which means mucus) [1]. Later, the German physician Conrad Victor Schneider

المحلة الصحية لشرق المتوسط، منظمة الصحة العالمية، المجلد الحادي عشر، العدد با، 0 • + 
(1614-80) cast doubt on the mucus secreting function of the pituitary when he first described the cribriform plate of the ethmoid [1]. But this view persisted until Pierre Marie (1853-1940) detected two cases of acromegaly with associated pituitary enlargement in 1886 and 1888 [3]. Since then a large body of knowledge has accumulated about the pituitary which led Langdon Brown in 1935 to describe it as the "leader of the endocrine orchestra".

\section{Anatomy of the thyroid}

The anatomy of the thyroid gland can be traced back as far as the first century AD when Galen, the famous Greek doctor, briefly described it in his treatise De voce [1]. In 1543 Vesalius gave a full description of the organ; he believed that it consisted of two separate parts [1]. Later, the anatomist Bartolomeo Eustachius recognized the isthmus and considered the thyroid as a single organ [1]. But the controversy about whether the thyroid was a single or double organ was finally resolved by Giovanni Bathista Morgagni (1682-1771) who demonstrated that the gland had two lobes connected by the isthmus. Thomas Wharton of London (1617-73) named the thyroid in 1656 , from the Greek word thyreos meaning "oblong shield" [3].

The histology of the thyroid was studied from the start of the microscopy era. It was found to be formed of vesicles containing colloid material and lined with cubical cells. The vesicles were thought to be communicating together, but in 1841, Heinrich Bardeleben of Germany (1817-95) refuted this idea [1].

\section{Physiology of the thyroid}

Throughout history, the function of the thyroid has been controversial. Galen sug- gested that it functioned to lubricate the larynx and this view was accepted for a long time. Wharton in 1656 suggested that the purpose of the thyroid was to beautify the neck by giving it a rounded contour through filling the vacant spaces around the larynx [3]. In 1829 Astley Cooper proposed that the thyroid was a lymphatic gland when he noticed lymph passing from it to the thoracic duct [1]. Even up to 1880 the thyroid was proposed as a receptacle of worms or even a vascular shunt to cushion the brain against a sudden increase in blood flow.

Thomas King (1809-47) first suggested the concept of an internal secretary function for the thyroid. King's idea was that the thyroid formed and secreted a vital material into the circulation at a time of emergency [4]. This view was supported a few years later by Felix Semon [1]. In 1856 Moritz Schiff (1823-96) of Berne carried out thyroidectomies on $\operatorname{dogs}$ and guinea pigs with fatal results [3]. For 30 years nothing was heard of this work. The thyroidectomy remained generally fatal until French physiologist Eugene Gley (18571934) described the parathyroid glands in 1891 [5].

In 1882-83, Ludwig Rehn (1849-1930) and Jacques-Louis Reverdin (1841-1917) noticed the appearance of symptoms of hypothyroidism after thyroidectomy operations on patients with Graves disease (see later) [6,7]. In 1884 Schiff remembered his 1856 work and repeated his previous experiments on dogs and succeeded in preventing the effects of thyroidectomy by grafting the thyroid onto another part of the animal body. Unfortunately, the body soon absorbed the gland. Thereafter, the function of the thyroid gland was thought to neutralize or remove poisons from the body and hence that thyroid deficiency leads to toxaemia.

المُلة الصحية لشرق المتوسط، منظمة الصحة العالمية، المجلد الحمادي عشر، العلد ب، 0 • + 
The definite function of the thyroid as a controller of metabolism was studied and confirmed by work carried out between 1886 and 1895 by George Murray (18651939), Hector Mackenzie (1856-1938) and Edward Fox (1856-1938) [8]. These studies were based on following up the successful effects of giving thyroid extracts by different routes to patients with myxoedema [8].

From around 1895 thyroid researchers began to study the chemistry of the gland secretions. This field was pioneered by Eugen Baumann (1846-97) who was the first to recognize the role of iodine in the work of the thyroid gland when he discovered a high concentration in the gland [9]. In 1896, he isolated a compound containing iodine (iodothyrin) and suggested a relation to iodine metabolism. In the same year, English paediatrician Robert Hutchison (1871-1960) found that iodine was concentrated in the colloidal material within the glandular follicles [10]. In 1899 Oswald extracted an iodized protein which he termed "thyeroglobin" [11]. The presence of organic iodine in the plasma was indicated by Gley and Bourcet in 1900 whereas in 1905 di-iodotyrosine was prepared by Wheeler and Jamieson [3]. Tri-iodothyronine, in plasma and thyroid, was recognized in 1952 by Gross and Pitt-Rivers [12]. The big success came in 1914 when Edward Kendall (1886-1970) isolated an iodine-containing crystalline product from alkaline hydrolyses of thyroid tissues and named it "thyroxine" [13]. He described it as a "stirring activator of metabolism and probably the hormone of the thyroid" [13]. By then, the active principle of the thyroid gland had been identified and then synthesized in 1927 by Charles Harrington (18781965) and George Barger (1878-1939) [14].

\section{Pituitary and thyroid}

The association between the pituitary gland and endocrine disease was first recognized by Pierre Marie in 1890 who found that pituitary enlargement was a constant finding in acromegaly patients $[3,15]$. In 1910 Crowe, Cushing and Homans performed complete hypophysectomies in $100 \mathrm{dogs}$ and reported a characteristic series of symptoms-bradycardia, hypothermia, ataxia and loss of consciousness [16]. The same symptoms followed removal of the anterior pituitary alone. During the 1930s enthusiastic and successful research was carried out to separate and isolate the various hormones of the anterior pituitary. One of them was thyroid-stimulating hormone (TSH), which was identified, by Collip and Anderson in 1935 [17]. In the 1970s TSH was found to be a glycoprotein and was assigned a molecular weight between 26000-30000 by Pierce and Wynston [5].

In 1938 it was first suggested that the engineering concept of "feedback control" could be applied to biological systems. Soon after, this was applied by Hoskins in endocrinology, who coined the term "thyrostat" [18]. The phrase "pituitary-thyroid axis" was first used in the 1940 s to describe the relationship of the two glands.

\section{Hypothalamus and thyroid}

In 1948 Harris proposed that the hypothalamus served as the key link between the endocrine and nervous systems in reacting to the surrounding environment [19]. In 1951, Monte Greer confirmed that inducing hypothalamic lesions (between the paraventricular nuclei and the median eminence) prevented the usual response to the antithyroid drug thiouracil (i.e. thyroxin inhibition and TSH overproduction) [20]. In 1955 Saffran, Schally and Benfey postulated that first-order hormones interacted in 
the hypothalamus to regulate the secretion of the pituitary hormones and they coined the term "releasing factors" for these hormones [21]. This was the first convincing report of the role of the hypothalamus in regulating pituitary hormones [21].

\section{Simple goitre and cretinism}

Descriptions of goitre have been found in Hindu writings earlier than $1500 \mathrm{BC}$ [1]. In the same period the Chinese used burnt sponge and seaweed in the treatment of goitre [1]. Hippocrates was aware of goitre. In the Middle Ages goitre was mentioned in the book Lives of saints and around this time, the word "goitre" was coined [1]. The presence of goitre was considered a sign of beauty in some societies. Also, the high prevalence of goitre in adults made it difficult to associate it with disease. Only from the work of Caleb Parry and Giuseppe Flajani at the beginning of the 19 th century was goitre recognized as a source of pathological effects [22]. Hence the term "toxic goitre" was introduced.

Chatin in 1853 in France was the first to describe the correlation between the iodine content of water, soil and air and the prevalence of goitre [23]. This information was neglected until confirmed in 1923 by Von Fellenverg in Switzerland and Orr in England [1]

Paracelsus recognized the coexistence of endemic goitre and cretinism in the middle of the 16th century in the Duchy of Salzburg [24]. Also in this century the first explorers of Colombia described "heavy and stupid savage of sluggish rabbits" [1]. The virtual disappearance of cretinism from Switzerland after introduction of iodized salts in the 1920s gave a convincing proof about the relationship between endemic goitre and cretinism.

But the question was raised whether iodine deficiency was the only cause for goi- tre. This issue was studied in India by Robert McCarrison who started a laboratory for nutrition research in 1918. He hypothesized the presence of "goitrogens" that inhibit thyroid function in the drinking water as a cause of goitre [25]. In 1928 Chesney and his co-workers were the first to observe that cabbage may contain goitrogens and cause goitre in rabbits (originally they were working on syphilis research and were using cabbage-fed rabbits) [26]. During the next decade a large number of vegetables were found to be goitrogenic e.g. cauliflowers, turnip and Brussels sprouts.

Burnt sponge and seaweed have been used in the treatment of goitre since the 12 th century. After extensive work with these materials, the chemist Bernard Courtois in France extracted a substance in 1812 [1]. This was examined by Humphry Davy, then at Paris who named it iodine. Four years later, the English physician William Prout tested potassium iodide on himself to make sure that it was not toxic in small amounts and then he used it as a remedy for goitre [1]. But the first genuine therapeutic trial to use iodine was made by Jean-Francois Coindet of Geneva (17741834) in 1820 [27]. He gave a tincture of iodine to 150 patients with goitre without ill-effects [27]. In 1829, Jean Lugol (17861851) of Paris introduced his well-known iodine solution (originally used to treat tuberculosis).

The use of iodine to prevent goitre was established in 1909-13 when Marine and Lenhart, in the USA, demonstrated the role of iodine deficiency in causing goitre in black trout and other animals [28]. During 1917-20 Marine and Kimball gave sodium iodide $(2 \mathrm{~g}$ in divided does twice yearly for 3 years) to 2000 schoolgirls in the goitre belt in Ohio, USA [29]. This regimen resulted in a reduction of cases from $87.6 \%$ in 1917 to $13.1 \%$ in 1922 [29].

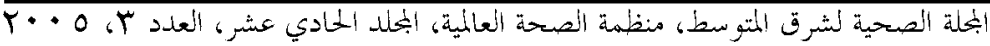


The surgical treatment of goitre was probably first attempted by Albucasis, a prominent Arab surgeon in the Middle Ages. The first surgeon who achieved successful results with thyroidectomy was Theodor Billroth at Vienna in 1849. But the techniques of this operation were highly improved by Theodor Kocher at Berne [1]. He performed more than 7000 thyroidectomies in his clinic with a mortality rate of $4.5 \%$ [1]. He was awarded the Noble prize in 1909 for pathology and surgery of thyroid disease, the first surgeon to win the prize.

\section{Hypothyroidism}

Up to 1850 doctors were familiar with the syndrome of cretinism but only in that year was the occurrence of features similar to cretinism in adults (i.e. myxodema) first reported by Thomas Blizzard Curling (1811-88) [30]. Curling noted the connection of absence of thyroid tissues with symmetrical swelling of fat tissues at the sides of the neck in two of his patients [30]. William Gull (1816-90) who was a prominent pathologist at Guy's Hospital, London gave a complete description of myxoedema in 1873, describing five cases of cretinism in adult women [31]. But it was William Ord (1834-1902) who in 1878 coined the term "myxoedema" when he found extensive deposits of mucin in the skin of feet of his patients at autopsy [32].

After 1880 researchers started to investigate the exact cause, and then to propose a suitable treatment for myxoedema. In 1882, Reverdin noted the occurrence of symptoms of myxoedema after thyroidectomy [6]. Also in 1883, Kocher in his Berne clinic described features of myxoedema in 30 out of 100 patients after thyroidectomy [1]. Kocher attributed these features to chronic asphyxia and termed them "cachexia strumipriva". Around the same time, Victor Horsley (1857-1919) produced artificial myxoedema in dogs after thyroidectomy [3]. Then in the second half of 1883 a controversy followed between Kocher and Reverdin regarding the nature of the postoperative myxoedema-like syndrome [3]. Felix Semon (1849-1921) put an end to this controversy by stating that myxoedema and cachexia struamiprivia were one disease and, together with cretinism, were due to one cause: loss of thyroid function [3]. Semon's statement was investigated and confirmed by a committee appointed by the Clinical Society of London (included, among others, Victor Horsley and Moritz Schiff).

The road was now paved to propose a suitable treatment for hypothyroidism. In 1886 Horsley and Schiff tried to transplant the thyroid but achieved only temporary success as the body soon absorbed the transplanted gland [1]. George Murray in 1891 and Howitz in 1892 tried to treat myxoedema with injection of thyroid extracts with successful results [33]. One of Murray's patients lived for a further 28 years after he was treated with hypodermic injections of glycerine extract of sheep thyroid tissue for 6 months [33]. At the same time, Hector Mackenzie was successful in giving patients fresh thyroid extract by mouth [8]. But most patients had to wait until thyroxine was isolated and then synthesized 35 years later [14].

An interesting historical point is that after myxoedema was fully described between 1873 and 1883 we notice a slow advancement in knowledge about it. This may be attributed to the early discovery of an extremely simple and efficient therapy that reduced the impetus for exhaustive research. But associations of myxoedema with certain clinical problems were described between 1949 and 1963. Examples

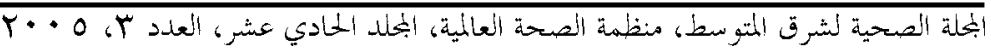


include pericardial effusion (1949) by R.A. Kern, myxoedema coma (1953) by Le Marquand, cerebellar disorder (1960) by Jellinek and Kelly, pernicious anaemia (1960) by Wilson and Tudhope and ascites (1963) by Atkinson.

The historical aspects of hypothyroid diseases other than myxoedema deserve to be mentioned in this article. Riedel in 1896 described a chronic non-malignant involvement of the thyroid gland (chronic thyroiditis) [34]. In 1912, Hashimoto first described the disease that now bears his name [35]. He described four cases of goitre whose histological features included atrophic epithelium, prominent lymphoid follicles and new abundant connective tissues [35]. At first there was argument about whether the disease was a separate entity or an early stage of Riedel disease. This controversy was not settled until the demonstration of serum antibodies in Hashimoto disease in 1956, which stimulated extensive investigations of this phenomenon. In fact, the first evidence of a possible role for autoimmunity in thyroid disease was the tendency of Hashimoto disease to pass sooner or later into hypothyroidism or even an early phase of thyrotoxicosis. In 1936 a third variety of thyroiditis (subacute and non-suppurative) was described by De Quervain and now bears his name [36].

\section{Hyperthyroidism}

The first person to describe the features of hyperthyroidism (later known as Graves disease) was Caleb Hillier Parry (17551822 ) in 1786 [22]. He was a highly esteemed practitioner at Bath, England. Parry saw five cases of exophthalmic goitre, palpitation and anxiety [22]. He described his patients as follows: "eyes were protruded from their sockets, faces exhibited an ap- pearance of agitation and distress, the heart beat was so violent that each systole of the heart shook the whole thorax..." [22]. Parry attributed these symptoms to alterations in the cardiac function. Also in a paper published after his death, Parry described a case of exophthalmos associated with goitre and 'non-organic heart disease' (to explain palpitation). Although Parry was the first to recognize hyperthyroidism, the first published work about it was by Giuseppe Flajani in 1802 [3].

In 1833 Robert James Graves (17961853) of Dublin (who was one of the founders of the Park Street School of Medicine) published a description of exophthalmic goitre so admirable that the disease still goes by his name (although Parry recognized it 47 years earlier) [37]. Like Parry, Graves erroneously thought that the disease was produced by alterations in cardiac function. To quote, "the sudden manner in which the thyroid used to increase and then diminish in size and the connection of this with the state of the heart's action are circumstances which may be considered as indicating that the thyroid is slightly analogous in structure to the tissues properly called erectile" [37].

In 1840, Graves disease was described by Adolph von Basedow (1779-1854) of Germany who completed the picture of toxic goitre [38]. Exophthalmos was noted in only one of the three cases described by Graves but was described in all Basedow's four cases [38]. Because Basedow had practised in Merseburg, the characteristic signs of Graves (goitre, exophthalmos and palpitation) were frequently called "Meresberg's triad". Basedow also mentioned other thyrotoxic features such as restlessness, wasting and diarrhoea [38].

At different times, many causes and pathogenetic mechanisms for Graves disease have been suggested. Parry and

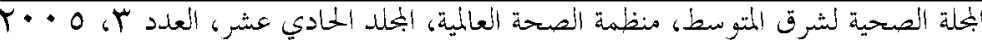


Graves, as explained above, suggested a cardiac lesion. Up to 1880 the etiology of hyperthyroidism was thought to be a lesion of the nervous system. In 1880 Ludwig Rehn of Frankfurt performed the first thyroidectomy for a patient with Graves disease [7]. The improvement in symptoms and signs lead Rehn to propose that the clinical features of this disease were due to hyperactivity of the thyroid gland [7]. In 1886 Rehn's view was supported by Paul Julius Mobius of Leipzig who suggested an abnormal activity of the thyroid that "poisoned" the body. The final word on this issue was from William Osler who speculated in 1909 that the symptoms of Graves disease were "due to disturbed function of the thyroid gland, probably a hypersecretion of certain materials which induce a sort of chronic toxaemia" [1]. The term hyperthyroidism was suggested by Charles Mayo in 1907. In 1924 Henry Plummer and Walter Boothby of the Mayo Clinic advanced the view that in Graves disease the thyroid produces excessive amounts of thyroxine (which had been isolated nine years earlier). The persistence of exophthalmos after thyroidectomy led the researchers to conceive of an exophthalmos-producing substance, produced outside the thyroid. During the 1930s the pituitary gland was suspected to be the source of exophthalmos-producing substance. For this reason Graves disease was treated in some centres at that time by pituitary irradiation. In 1952 Marcus and his co-workers reinvestigated exophthalmosproducing substance, which was later called long-acting thyroid simulator (LATS) by Adams and co-workers [39].

\section{Therapy}

By the time therapeutic trials were beginning to test a drug to treat hyperthyroidism there was an established association be- tween endemic goitre and hypothyroidism. Thus the development of these drugs was based on the theory that any agent that can cause goitre might be useful in treating hyperthyroidism. Since 1928 some plants including cabbage and turnip were found to be goitrogenic [26]. Thus the idea of developing anti-thyroid drugs was borne [1]. In this context, cyanide radicals which were once thought to be goitrogenic were tried as anti-thyroid agents but without success. In 1942 goitre was noticed as a side effect in hypertensive patients using thiocyanates and these drugs were tested in the treatment of hypothyroidism but with little success.

In early 1940s it was reported that the administration of sulfonamides in rats resulted in thyroid enlargement and a decrease in metabolic activity. These effects were thought to be due to inhibition of synthesis of thyroid hormones. But sulfonamides proved little value in the treatment of hyperthyroidism [1].

At the same period Astwood in the USA achieved promising results with thiouracil. Thereafter thiouracil compounds were developed and after 1943 used clinically to treat hyperthyroidism [40]. Although they initially gained a bad reputation due to toxic side-effects, this problem was resolved by decreasing the dose. Carbimazole was introduced in 1952, and still remains the most widely used anti-thyroid drug.

Before the performance of thyroidectomy to treat hyperthyroidism there were two types of surgical operations that were tried without success. In 1854 the ligation of the inferior or superior thyroidal artery was described [1]. William Moore in 1865 suggested that palpitations in Graves disease were due to increased sympathetic activity and several surgeons suggested resection of the cervical sympathetic chain [1]. As mentioned above, Rehn was the

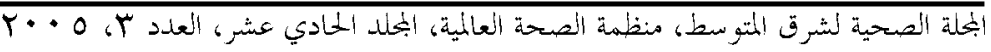


first to perform subtotal thyroidectomy for Graves disease but for a few years earlier thyroidectomy had been introduced to treat simple goitre [7]. Safer thyroidectomy was made possible by the introduction of preoperative use of iodine in 1923.

Although Saul Hertz and Howard Means realized that radioiodine could be made and used as a tracer, the idea of use of radioiodine in endocrine research was first suggested in 1937 in a lecture given by President Compton of the Massachusetts Institute of Technology [41]. In 1938 Robley Evans and Arthur Roberts made the short-lived $\mathrm{I}^{128}$ and studied its physiology in rabbits. This was the first practical use of a labelled substance to study its uptake in animals after its intravenous injection [41]. The only drawback of $\mathrm{I}^{128}$ that hindered its use as a therapy was its very short half-life (25 minutes). Then in 1939 Joseph Hamilton and Mayo Soley at California made two radioiodines, $\mathrm{I}^{130}$ and $\mathrm{I}^{131}$, with half-lives of 12 hours and 8 days respectively. They were the first radioiodines used to study iodine physiology in humans. The next step was to use these radioiodines in treatment of hyperthyroidism. This was first performed by Hertz and Roberts in 1941 at Harvard General Hospital, and soon the effectiveness of this therapy was proved [41].

\section{Conclusion}

As we have seen, the history of thyroid disease gives an interesting insight into the inter-relationship of basic and clinical sciences. The understanding of the pathogenesis and therapeutic trials of thyroid disease went hand in hand with the discovery of the physiological aspects of the thyroid gland. From the middle of the nineteenth century onwards, researchers gradually elucidated the anatomy, physiology and function of the thyroid which has led to the current diagnostic techniques and therapies available today. And the work continues in order to further our understanding of this important gland and improve and refine our diagnosis and treatment of thyroid dysfunction.

\section{References}

1. Singer C, Underwood EA. A short history of medicine, 2nd ed. Oxford, Oxford University Press, 1962:519-34.

2. Bernard C. Piqure diabetes. Memorna societa de biologica, 1849, 1:80-92.

3. Hughes AF. A history of endocrinology. Journal of the history of medicine and allied sciences, 1977, 32:292-313.

4. King TW. Observations on the thyroid gland. Guy's Hospital report, 1856, 1: 429-47.

5. Gley E. Sur les fonctions du corps thyroide. CR Società Biologica, 1891, 48:429-35.

6. Reverdin JL. Accidents consécutifs à l'ablation totale du goitre. Reviera medica suisse rom, 1882, 2:539.
7. Rehn L. Uber die extirpation des Kropfs bei morbus Basedowii. Berlin Klinica Wescher, 1884, 21:163-6.

8. Mackenzie HWG. A case of myxoedema treated with great benefit by feeding with fresh thyroid glands. British medical journal, 1892, 2:940-1.

9. Baumann E. Uber das normale Vorkommen Von Jod in Thierkorper. Hoppe-Seyler's Zeitschrift fur physiologische Chemie, 1895-1896, 21:31930.

10. Hutchison R. The chemistry of the thyroid gland and the nature of its active constituents. Journal of physiology, 1896, 20:474-96.

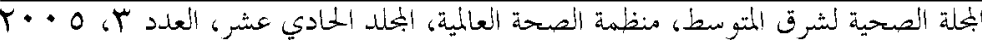


11. Oswald A. Die Eiweisskorpor der Schilddruse. Hoppe-Seyler's Zeitschrift fur physiologische Chemie, 1899, 27: 14-21.

12. Gross J, Pitt-Rivers R. Tri-iodothyronine in relation to thyroid physiology. Recent progress in hormone research, 1954, 10:109-24.

13. Kendall EC. The isolation of a compound containing iodine in the thyroid. Journal of the American Medical Association, 1915, 64:2042-3.

14. Harrington $C R$, Barger G. Constitution and synthesis of thyroxine. Biochemistry journal, 1927, 21:169-81.

15. Marie P. Acromegaly. Brain, 1890, 12:5981.

16. Crowe SJ, Cushing H, Homans J. Experimental hypophysectomy. Bulletin of the Johns Hopkins Hospital, 1910, 21: 121-69.

17. Collip JB, Anderson EM. Studies on the thyrotropic hormone of the anterior pituitary. Journal of the American Medical Association, 1935, 104:965-6.

18. Hoskins RG. The thyroid-pituitary apparatus as a servo (feed-back) mechanism. Journal of clinical endocrinology, 1949, 9:1429-31.

19. Harris GW. Natural control of the pituitary gland. Physiological review, 1948, 28: 139-79.

20. Greer M. Evidence of a hypothalamic control of pituitary release of thyrotrophin. Proceedings of the Society of Experimental and Biological Medicine, 1951, 77:603-8.

21. Saffran M, Schally AV, Benfey BG. Stimulation of the release of corticotropin from the adenohypophysis by a neurohypophysial factor. Endocrinology, 1955, 57: 439-49.

22. Parry $\mathrm{CH}$. Collections from the unpublished medical writings of the late Caleb
Hillier Parry (volume 2). London, Underwoods, 1825:111.

23. Chatin M. Presence de iode dans les eaux pluviales, les plantes des Antilles et des cotes de la Mediterranee. $C R$ Academa Scienca, 1853, 37:723-4.

24. Paracelsus M. De generative stultorum. Liber theophrasti. In: Omnia opera tractatus. Rome, 1603, volume 1.

25. McCarrison R. Observations on endemic goitre. Lancet, 1908, 2:1275-80.

26. Chisney AM, Clawson TA, Webster B. Endemic goiter in rabbits. Bulletin of the Johns Hopkins Hospital, 1928, 43:26175.

27. Coindet JF. lodine: on its application as a medicine. Quarterly journal of science, 1821, 11:408.

28. Marine D, Lenhart $\mathrm{CH}$. Observations and experiments. Journal of experimental medicine, 1910, 12:311-20.

29. Marine D, Kimball OP. The prevention of simple goitre in man. Archives of internal medicine, 1920, 25:661-74.

30. Curling TB. Two cases of absence of the thyroid body, and symmetrical swellings of fat tissue at the sides of the neck, connected with defective cerebral development. Medico-chirurgical transactions, 1850, 33:303-6.

31. Gull WO. On a cretinoid state supervening in adult life in women. Transactions of the Clinical Society of London, 1873, 7:180-5.

32. Ord WM. On myxoedema, a term proposed to be applied to an essential condition in the cretinoid affection occasionally observed in the middleaged women. Medico-chirurgical transactions, 1878, 61:57-78.

33. Murray G. Notes on the treatment of myxoedema. British medical journal, 1891, 2:796-7.

المجلة الصحية لشرق المتو سط، منظمة الصحة العالمية، المجلد الحمادي عشر، العلد ب، 0 • • 
34. Riedel B. Vorstellung eines Kraken mit chronischer Strumitis. Ver Deutsch Ges Chirurgica, 1897, 26:127-31.

35. Hashimoto H. Zur Kenntniss der lymphomatosen Veranderung der Schilddruse (struma lymphomatosa). Archiv fur klinische Chirurgie, 1912, 97:219-25.

36. De Quervain F, Giordanengo G. Die akute and subacute nicht Eiterige. Thyroiditis. Mitt Grenzgeb Medica Chirurgica, 1936, 44:588-93.

37. Graves RJ. Newly observed affection of the thyroid gland. London medical and surgical journal, 1835, 7:516-7.

38. Von Basedow CA. Exophthalmus durch Hypertrophie des Zellgewebes in der
Augenhöhle. Wochenschrift für die gesammte Heilkunde, 1840, 6:197-204.

39. Adam DD, Beavan DW. The presence of abnormal thyroid stimulator in the blood of thyrotoxic patients. Journal of clinical endocrinology and metabolism, 1962, 68: 154-65.

40. Astwood EB. Treatment of hyperthyroidism with thiourea and thiouracil. Journal of the American Medical Association, 1943, 122:78-85.

41. Sawin CT, Becker DV. Radioiodine and the treatment of hyperthyroidism: the early history. Thyroid, 1997, 7:163-76.

\section{Corrections}

Schoolteachers' knowledge of common health problems in Bahrain. F.A. Alnasir and J.H. Skerman. Eastern Mediterranean Health Journal, 2004, Vol. 10 Nos 4/5, pages 537-546. In the abstract: The name in Arabic of the first author should read: فيصل الناصر، جونتان سكرمان

Frequency of the CCR5-delta 32 chemokine receptor gene mutation in the Lebanese population. W. Karam, R. Jurjus, N. Khoury, H. Khansa, C. Assad, P. Zalloua and A. Jurjus. Eastern Mediterranean Health Journal, 2004, Vol. 10 Nos 4/5, pages 671-675.

The chemokine receptor gene in the title of the article on page 671 was not printed correctly and should read: CCR5-delta 32.

المُلة الصحية لشرق المتوسط، منظمة الصحة العالمية، المجلد الحمادي عشر، العلد ب، 0 • + 